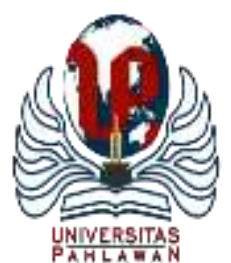

\title{
JURNALBASICEDU
}

Volume 5 Nomor 5 Tahun 2021 Halaman 3551 - 3558

Research \&Learningin Elementary Education

https://jbasic.org/index.php/basicedu

\section{Studi Komparasi Kepercayaan Diri (Self Confidance) Siswa yang Mengalami Verbal Bullying dan Yang Tidak Mengalami Verbal Bullying di Sekolah Dasar}

\author{
Indriana Ulul Azmi ${ }^{1 凶}$, Nafi'ah $^{2}$, Muhammad Thamrin $^{3}$, Akhwani $^{4}$ \\ Pendidikan Guru Sekolah Dasar, Universitas Nahdlatul Ulama Surabaya, Indonesia ${ }^{1,2,3,4}$ \\ E-mail: indriazmi281@gmail.com ${ }^{1}$, nefi_23@unusa.ac.id ${ }^{2}$, Thamrin@unusa.ac.id ${ }^{3}$, $\underline{\text { akhwani@unusa.ac.id }}^{4}$
}

\begin{abstract}
Abstrak
Tujuan dari penelitian ini adalah untuk menganalisis kepercayaan diri (self confidence) siswa yang mengalami verbal bullyingdan yang tidak mengalami verbalbullying, serta untuk menguji ada tidaknya perbedaan antara kepercayaan diri (self confidence)siswa yang mengalami verbal bullying dengan yang tidak mengalami verbal bullying. Metode yang digunakan dalam penelitian ini adalah kuanitatif dengan metode penelitian komparatif. Teknik pengambilan sampel menggunakan teknik purposive sampling dengan kriteria-kriteria yang sudah ditentukan oleh peneliti. Teknik analisis data yang digunakan adalah uji analisis statistic deskriptif dan uji man whitney. Hasil penelitian yang didapat adalah 10 dari 30 responden mengalami tindakan verbalbullying dan memiliki kepercayaan diri yang rendah, hal ini dapat dilihat dari hasil perhitungan analisis statistic deskriptif yang memperoleh skor $>60 \%$ sedangkan untuk kepercayaan diri siswa yang tidak mengalami tindakan verbalbullying memiliki kepercayaan diri yang tinggi. Kepercayaan diri siswa yang mengalami verbalbullying dengan kepercayaan diri siswa yang tidak mengalami verbalbullying terdapat perbedaan hal ini dibuktikan dengan perhitungan ujii man whitney yang memperoleh nilai Asymp. Sig sebesar 0,000 sehingga dapat diketahui bahwa $0,000<0,05$ maka $h_{0}$ ditolak sedangkan $h_{1}$ diterima, sehingga ada perbedaan antara kepercayaan diri siswa yang mengalami verbal bullying dengan kepercayaan diri siswa yang tidak mengalami verbal bullying.
\end{abstract}

Kata Kunci: studi komparasi, kepercayaan diri, verbal bullying.

\begin{abstract}
The purpose of this study was to analyze the self-confidence of students who experienced verbal bullying and those who did not experience verbal bullying, as well as to test whether there was a difference between the self-confidence of students who experienced verbal bullying and those who did not experience verbal bullying. The method used in this study is quantitative with comparative research methods. The sampling technique used purposive sampling technique with the criteria that have been determined by the researcher. The data analysis technique used is descriptive statistical analysis test and man whitney test. The results obtained were 10 out of 30 respondents experienced verbal bullying and had low self-confidence, this can be seen from the results of descriptive statistical analysis calculations that obtained a score of $>60 \%$ while students who did not experience verbal bullying had self-confidence. tall one. There is a difference in the confidence of students who experience verbal bullying with the confidence of students who do not experience verbal bullying, this is evidenced by the calculation of the man whitney test that gets the Asymp score. Sig is 0.000 so it can be seen that $0.000<0.05$ then $h_{-} 0$ is rejected while $h \_1$ is accepted, so there is a difference between the confidence of students who experience verbal bullying and the confidence of students who do not experience verbal bullying.
\end{abstract}

Keywords: comparative study, self-confidence, verbal bullying

Copyright (c) 2021 Indriana Ulul Azmi, Nafi'ah, Muhammad Thamrin, Akhwani

$\triangle$ Corresponding author :

Email : indriazmi281@gmail.com

DOI : https://doi.org/10.31004/basicedu.v5i5.1389

ISSN 2580-3735 (Media Cetak)

ISSN 2580-1147 (Media Online)

Jurnal Basicedu Vol 5 No 5 Tahun 2021

p-ISSN 2580-3735 e-ISSN 2580-1147 
3552 Studi Komparasi Kepercayaan Diri (Self Confidance) Siswa yang Mengalami Verbal Bullying dan Yang Tidak Mengalami Verbal Bullying di Sekolah Dasar-Indriana Ulul Azmi, Nafi'ah, Muhammad Thamrin, Akhwan

DOI: https://doi.org/10.31004/basicedu.v5i5.1389

\section{PENDAHULUAN}

Pada dasarnya kepercayaan diri merupakan kunci untuk meraih kesuksesan dalam setiap aspek kehidupan. Di dalam kehidupan setiap individu akan mengalami perubahan dalam setiap hal, lingkungan yang baru, teman-teman baru dan tidak semua individu dapat menyesuaikan diri dengan perubahan-perubahan yang ada disekitarnya. Lauster (2003; Amri, 2018) menyatakan bahwa ada beberapa aspek kepercayaan diri positif seseorang adalah self-efficacy, optimis, obyektif, bertanggung jawab rasional dan realistis. Kepercayaan diri merupakan suatu keyakinan dan sikap seseorang terhadap kemampuan pada dirinya sendiri dengan menerima secara apa adanya baik positif maupun negatif yang dibentuk dan dipelajari melalui proses belajar dengan tujuan untuk kebahagiaan dirinya (Ramadhani \& Putrianti, 2014)

Mastuti (2008;(Junaida, 2016) berpendapat bahwa kepercayaan diri merupakan sikap mental seseorang dalam menilai diri maupun objek sekitarnya sehingga orang tersebut memiliki keyakinan atau kemampuan dirinya untuk dapat melakukan sesuatu sesuai dengan kemampuannya. Kepercayaan diri merupakan fungsi langsung dari interpretasi seseorang terhadap keterampilan atau kemampuan yang dimilikinya (Kelas et al., 2013). Dari pemaparan diatas dapat disimpulkan bahwa kepercayaan diri merupakan aset penting dalam setiap individu karena pada dasarnya individu yang memiliki kecerdasan intelektual yang baik tapi tidak memiliki rasa kepercayaan diri maka akan berdampak pada kehidupannya. Setiap individu memiliki cara tersendiri untuk penyesuaian diri dilingkungan yang baru. Percaya diri adalah suatu perasaan dan keyakinan terhadap kemampuan yang dimiliki untuk dapat meraih kesuksesan dengan berpijak pada usahanya sendiri dan mengembangkan penilaian yang positif bagi dirinya sendiri maupun lingkungannya sehingga, seseorang dapat tampil dengan penuh keyakinan dan mampu menghadapi segala sesuatu dengan tenang (Fitri et al., 2018). Orang yang percaya diri bisa dilihat dari ketenangan mereka dalam mengontrol diri sendiri. Selain itu, orang yang percaya diri tinggi tidak mudah terpengaruh oleh situasi yang kebanyakan orang menilainya negatif, Sebab orang yang percaya diri biasa mengatasi rasa khawatir, takut dan cemas serta mampu mengatasi konfrontasi secara efektif dan konstruktif (Fatchurahman \& Praktikto, 2012). Kepercayaan diri memberikan kemampuan individu untuk mengatasi tantangan baru, meyakini diri sendiri dalam situasi sulit, melewati batasan yang menghambat, menyelesaikan hal yang belum pernah dilakukan, mengeluarkan bakat serta kemampuan sepenuhnya, dan tidak mengkhawatirkan kegagalan (Saputra \& Prasetiawan, 2018).

Menurut Psikolog W.H. Miskell (1939; Rosyida, 2013) telah mendefinisikan arti percaya diri dalam bukunya yang bertuliskan "Percaya diri adalah kepercayaan akan kemampuan sendiri yang memadai dan menyadari kemampuan yang dimiliki, serta dapat memanfaatkannya secara tepat". Namun, karena kurangnya percaya diri, individu seringkali tidak mampu beradaptasi dengan dirinya sendiri, akibatnya individu mengalami depresi, cuek serta tidak mau mengutarakan pendapat. Menurut purnawan (2009:Fitri et al., 2018) penyebab kurang percaya diri pada individu diantaranya, pengaruh lingkungan, sering diremehkan oleh teman sebaya, polah asuh orang tua yang sering melarang dan membatasi kegiatan anak, orang tua yang selalu memarahi kesalahan anak, tetapi tidak pernah memberi penghargaan apabila anak melakukan hal yang positif, kurang kasih sayang. Suatu pertemanan akan membentuk suatu hubungan, hubungan tersebut akan membentuk suatu kelompok bermain. Ada beberapa dampak sosial yang peneliti dapatkan dari perolehan penelitia, yaitu tentang pemanggilan nama yang tidak sesuai seperti "kriwil" karena salah satu siswa memiliki rambut yang agak kriwil, "hitam"karena memiliki kulit yang berwarna hitam. Hal tersebut akan mengarah pada tindakan dari bullying. Menurut Sejiwa (2008 dalam Remaja et al., 2018) kurangnya rasa percaya diri merupakan dampak yang terjadi bila seseorang mendapatkan perilaku bullying dari temannya.

Dalam (Ariesto, 2009) bullying adalah keinginan untuk menyakiti, menerapkan keinginan kedalam praktek yang membuat orang lain menderita, bullying tersebut dilakukan secara langsung oleh seseorang atau kelompok yang lebih kuat, tidak bertanggung jawab dan biasanya berulang dan dengan senang hati dalam 
3553 Studi Komparasi Kepercayaan Diri (Self Confidance) Siswa yang Mengalami Verbal Bullying dan Yang Tidak Mengalami Verbal Bullying di Sekolah Dasar-Indriana Ulul Azmi, Nafi'ah, Muhammad Thamrin, Akhwan

DOI: https://doi.org/10.31004/basicedu.v5i5.1389

melakukannya. Bullying erat kaitannya dengan pembentukan karakter individu, pendidikan karakter, penanaman nilai berhubungan dengan pembentukan sikap dan perilaku. Sekolah merupakan lingkungan kedua setelah keluarga, sekolah sangat memegang pengaruh penting dalam rangka membentuk karakter religius pada siswa (Ansulat Esmael, 2018). Jika karakter siswa baik, mereka akan secara tidak langsung akan berpikir tentang tindakan mereka kepada teman ataupun orang lain. Menurut Lestari dalam (Astuti \& Yusuf, 2015) berpendapat bahwa "bullying verbal terjadi ketika seseorang menggunakan bahasa lisan untuk mendapatkan kekuasaan atas korbannya". Bullying verbal meliputi menggoda, memberikan nama panggilan, membuat komentar seksual yang tidak pantas, mengejek, dan mengancam.

Perbedaan kepercayaan diri (self confidence) siswa yang mengalami verbal bullying cenderung rendah, mereka susah untuk bersosialisasi, minder, khawatir dengan masa depan dan mereka merasa tidak berguna. Sedangkan kepercayaan diri (self confidence) siswa yang tidak mengalami verbal bullying cenderung tinggi, mereka sangat mudah untuk bersosialisasi, tidak mudah merasa khawatir dan lebih bias mengugkapkan pendapat mereka.

Dengan mencermati kondisi diatas, peneliti tertarik melakukan penelitian dengan judul studi komparasi kepercayaan diri (self confidence) siswa yang mengalami verbal bullying dan siswa yang tidak mengalami verbal bullying di Sekolah Dasar;

Penelitian ini juga memiliki tujuan sebagai berikut: 1) untuk menganalisis kepercayaan diri (self confidence) siswa yang mengalami verbal bullying di SD 104 Gresik. 2) untuk menganalisis kepercayaan diri (self confidence) siswa yang tidak mengalami verbal bullying di SD 104 Gresik . 3) untuk menguji ada tidaknya perbedaan antara kepercayaan diri (self confidence)siswa yang mengalami verbal bullying dengan yang tidak mengalami verbal bullying di SD 104 Gresik.

Hasil penelitan yang dilakukan oleh Umara (2020) terdapat berbedaan tingkah laku antara siswa yang melakukan verbal bullying dan siswa yang menjadi korban verbal bullying tersebut. Siswa yang menjadi korban verbal bullying menjadi pendiam di kelas dan merasa kurang percaya diri dalam menyampaikan pendapat di muka umum. Siswa yang diejek temannya dengan dikatai "goblok" dan "dancuk" terkadang merasa sedih dan tidak ingin temannya melakukan hal demikian lagi. Akibatknya dia sering menghindari teman-teman yang mengatainya. Hasil penelitian juga menyebutkan adanya verbal bullying akan menganggu jalannya proses komunikasi antar siswa. Siswa menjadi kurang percaya diri dikarenakan label yang dimilikinya.

Hasil penelitian yang dilakukan oleh Faizal chan (2020) juga membuktikan bahwa terdapat perbedaan perilaku antara kepercayaan diri siswa yang mengalami verbal bullying dengan kepercayaan diri siswa yang tidak mengalami verbal bullying. korban bullying memiliki kecenderungan untuk dijauhi oleh temantemannya, temannya. Pada umumnya mereka sulit untuk dapat bersosialisasi dikarenakan hilangnya rasa percaya diri peserta didik yang menjadi korban bullying. Pada penelitian ini hasil analisis statistic deskriptif Kepercayaan diri siswa yang mengalami verbal bullying cenderung rendah, mereka jarang bisa memahami sesuatu, mereka juga selalu mengkhawatirkan tentang masa depan. Hal ini dibuktikan dengan perolehan hasil perhitungan sebesar 64,7\% dengan frekuensi 6 dan 70,4\% dengan frekuensi 4. Perolehan skor tergolong tinggi jika di interpretasikan dalam skala 60\%-80\%. Untuk perhitungan analisis statistik kepercayaan diri siswa yang tidak mengalami verbal bullying cenderung tinggi, mereka tidak mendapatkan tindakan verbal bullying, dibuktikan dengan perolehan skor presentase $<60 \%$ yang tergolong dalam kategori yang rendah. Kemudian untuk perhitungan uji mann whitney mendapatkan nilai skor asymsig sebesar 0.000 sehingga dapat disimpulkan bahwa terdapat perbedaan yang signifikan kepercayaan diri siswa yang mengalami verbal bullying dengan kepercayaan diri siswa yang tidak mengalami verbal bullying. Dari penjelasan dan perhitungan spss 16 diatas menunjukkan bahwa verbal bullying dapat memberikan pengaruh terhadap kepercayaan diri siswa. 
3554 Studi Komparasi Kepercayaan Diri (Self Confidance) Siswa yang Mengalami Verbal Bullying dan Yang Tidak Mengalami Verbal Bullying di Sekolah Dasar-Indriana Ulul Azmi, Nafi'ah, Muhammad Thamrin, Akhwan

DOI: https://doi.org/10.31004/basicedu.v5i5.1389

\section{METODE PENELITIAN}

Desain penelitian yang digunakan dalam penelitian ini menggunakan metode penelitian kuantitatif non eksperimen. Pada penelitian ini menggunakan jenis kuantitatif komparasi yang digunakan untuk membandingkan suatu variabel (objek penelitian), antara subjek yang berbeda atau waktu yang berbeda dan menemukan hubungan sebab-akibatnya mengetahui perbedaan antara variabel yang tidak berhubungan (Surakhmad, 2016). Sehingga penelitian ini bertujuan untuk menganalisis perbedaan kepercayaan diri siswa yang mengalami verbal bullying dan yang tidak mengalami verbal bullying di SD 104 Gresik.

Penelitian ini dilakukan di SD 104 Gresik SD 104 GRESIK. Lokasi penelitian berada di Jl. Kalipadang Dusun Kalipadang Desa Kalipadang Kecamatan Benjeng Kabupaten Gresik. Penelitian ini di fokuskan kelas V dan VI di SD 104 GRESIK. Menurut Sugiyono (2011; (Dewi \& Nathania, 2018)) populasi adalah wilayah generalisasi yang terdiri atas objek atau subjek yang mempunyai kualitas dan karakteristik tertentu yang ditetapkan oleh peneliti untuk dipelajari dan kemudian ditarik kesimpulannya. Populasi pada penelitian ini berjumlah 49 siswa gabungan dari jumlah siswa kelas V dan VI. Penarikan sampel menggunakan teknik sampling. Teknik sampling yaitu nonprobability sampling dengan teknik purposive sampling. Menurut sugiyono (2016; dalam Yustia Putri, 2017)) bahwa "purposive sampling adalah teknik pengambilan sampel sumber data dengan pertimbangan tertentu" alasan menggunakan teknik purposive sampling adalah karena tidak semua sampel memiliki kriteria yang sesuai dengan fenomena yang diteliti. Dari pemilihan sampel peneliti mendapatkan 30 sampel untuk dilakukan penelitian lebih lanjut. Teknik pengumpulan data yang digunakan dalam penelitian ini yaitu menggunakan angket/kuesioner. Dengan instrument didalam angket yang dibuat dalam butir-butir pertanyaan yang dibuat sesuai indikator yang akan diukur, sehingga dapat terarahkan oleh tujuan masalah dan hipotesis penelitian. Semua butir pertanyaan pada angket harus dijawab oleh reponden.

Pada penelitian ini menggunakan skala pengukuran guttman dengan mengggunakan dua alternatf jawaban (Ya, Tidak ) pengukuran setiap variabel dilakukan dengan mebuat lembaran angket. Lembaran angket disusun berdasarkan urutan data yang diperlukan dan jawaban yang sesuai dengan apa yang dirasakan. Sebelum dilakukan analisis data maka peneliti melakukan uji validitas dan uji reliabilitas. Uji validitas pada penelitian ini dilakukan dengan dua teknik yaitu validasi ahli dan validasi dengan spss versi 16 . Sedangkan uji reliabilitas pada penelitian ini menggunakan model alpha dengan bantuan program spss versi 16, untuk pengambilan keputusan suatu instrument dikatakan reliabel jika nilai Cronbach alpha lebih besar dari 0,7.

Teknik analisis data yang digunakan pada penelitian ini yaitu menggunakan teknik analisis data deskriptif presentase dan uji mann whitney. Teknik analisis deskriptif presentase digunakan untuk menguji kedua variabel pada penelitian ini, sedangkan analisis uji mann whitney merupakan teknik yang dipakai untuk menguji signifikansi perbedaan antara dua populasi, dengan menggunakan sampel dari populasi yang sama. Metode ini digunakan bilamana asumsi klasik diasumsikan terpenuhi (Harmila et al., 2017). Untuk mengetahui nilai signifikasi peneliti menggunakan bantuan program spss 16. Apabila (sig)<0,05 maka $h_{0}$ ditolak dan $h_{1}$ diterima, ada pengaruh variabel bebas (x) terhadap variabel terikat $(\mathrm{Y})$ atau hipotesis diterima.

\section{HASIL DAN PEMBAHASAN}

Data hasil penelitian penelitian meliputi hsil uji validitas dan reliabilitas kuisioner/angket, hasil analisis deskriptif serta hasil uji mann whitney. Adapun hasil penelitian sebagai berikut:

\section{Kepercayaan diri (self confidence) siswa yang mengalami verbal bullying}

Hasil perhitungan analisis statistik perolehan skor kepercayaan diri yang mengalami verbal bullying dapat dilihat dari tabel dibawah ini: 
3555 Studi Komparasi Kepercayaan Diri (Self Confidance) Siswa yang Mengalami Verbal Bullying dan Yang Tidak Mengalami Verbal Bullying di Sekolah Dasar-Indriana Ulul Azmi, Nafi'ah, Muhammad Thamrin, Akhwan

DOI: https://doi.org/10.31004/basicedu.v5i5.1389

Tabel1 presentase tingkat kepercayaan diri (self confidence) siswa yang mengalami verbal bullying

\begin{tabular}{cccc}
\hline No & Frekuensi & Presentasi & Kategori \\
\hline 1 & 4 & $64,7 \%$ & X tinggi, Y rendah \\
\hline 2 & 6 & $70,5 \%$ & X tinggi, Y rendah \\
\hline
\end{tabular}

Dari hasil tersebut menunjukkan bahwa tingkat verbal bullying tinggi hal ini dapat dilihat dari tabel analisis statistik dalam interval 60\% - 80\%. kepercayaan diri (self confidence) siswa yang mengalami verbal bullying tergolong rendah, dilihat dari tabel 1 semakin tinggi presentase yang didapat semakin tinggi verbalbullying dan semakin rendah kepercayaan diri siswa. Penelitian tentang studi komparasi kepercayaan diri (self confidence) siswa yang mengalami verbal bullying dan kepercayaan diri (self confidence) siswa yang tidak mengalami verbal bullying. Kepercayaan diri siswa yang mengalami verbal bullying cenderung rendah, mereka jarang bisa memahami sesuatu, mereka juga selalu mengkhawatirkan tentang masa depan. Akibat yang dirasakan oleh siswa korban bullying verbal relevan terhadap penelitian yang dilakukan Faizal Chan (2019) yang menyebutkan bahwa bullying verbal mengakibatkan korban pembullyan mengalami masalah psikis yang menyebabkan mereka kurang bersosialisasi, minder dan kepercayaan diri mereka menurun.

Kepercayaan diri merupakan salah satu aspek kepribadian yang penting bagi seseorang. Tanpa adanya kepercayaan diri akan banyak menimbulkan masalah pada diri seseorang dalam kehidupan bermasyarakat. Dikarenakan kepercayaan diri, seseorang mampu meaktualisasikan segala potensi dirinya. Hal ini sejalan dengan teori Al-Uqshari (2005;Prasetiawan \& Saputra, 2018) rasa percaya diri adalah salah satu kunci kesuksesan dalam hidup. Untuk mencapai kesuksesan hidup individu, kepercayaan diri sangatlah penting agar kita bisa memaksimalkan potensi yang ada pada diri kita, maupun dalam pergaulan bermasyarakat. Menurut Al-Uqshari tanpa adanya rasa percaya diri, individu tidak akan bisa mencapai keinginan yang kita impikan, bahkan vitalitas, daya kreatifitas dan jiwa petualangan yang dimiliki akan berubah menjadi depresi, frustasi dan patah semangat. Karena pada dasarnya,rasa percaya diri secara alami dapat memberikan kita efektifitas kerja, kesehatan lahir batin, kecerdasan, keberanian, vitalitas, daya kreatifitas, jiwa petualangan, kemampuan mengambil keputusan yang tepat, kontrol diri, kematangan etika, rendah hati, sikap toleren, rasa puas dalam diri maupun jiwa, serta ketenangan jiwa. Maka dapat diartikan bahwa kepercayaan diri sangat penting bagi setiap individu karena tanpa adanya kepercayaan diri individu tersebut akan susah mengahadapi kehidupan. Kepercayaan diri memiliki fungsi sebagai pendorong siswa untuk meraih kesuksesan, untuk itu siswa yang menjadi korban bullying perlu diberikan perhatian khusus dan memfokuskan pada kelebihan yang dimiliki, serta mengurangi kelemahannya.

\section{Kepercayaan diri (self confidence) siswa yang tidak mengalami verbal bullying}

Hasil data yang diperoleh dari perhitungan analisis statistik. Hasil yang diperoleh dapat dilihat pada tabel dibawah ini.

Tabel 2 presentase tingkat kepercayaan diri (self confidence) siswa yang tidak mengalamiverbal bullying

\begin{tabular}{cccc}
\hline No & Frekuensi & Presentasi & Kategori \\
\hline 1 & 1 & $29.4 \%$ & X rendah, Y tinggi \\
\hline 2 & 2 & $41.2 \%$ & X rendah, Y tinggi \\
\hline 3 & 7 & $47 \%$ & X rendah, Y tinggi \\
\hline 4 & 4 & $52 \%$ & X rendah, Y tinggi \\
\hline 5 & 6 & $58.8 \%$ & X rendah, Y tinggi \\
\hline
\end{tabular}


3556 Studi Komparasi Kepercayaan Diri (Self Confidance) Siswa yang Mengalami Verbal Bullying dan Yang Tidak Mengalami Verbal Bullying di Sekolah Dasar-Indriana Ulul Azmi, Nafi'ah, Muhammad Thamrin, Akhwan

DOI: https://doi.org/10.31004/basicedu.v5i5.1389

Dari hasil tersebut menunjukkan bahwa tingkat verbal bullying tergolong rendah hal ini dapat dilihat dari tabel analisis statistik dalam interval 60\% - 80\%. kepercayaan diri (self confidence) siswa yang tidak mengalami verbal bullying tergolong tinggi, dilihat dari tabel 2 semakin rendah presentase yang didapat semakin rendah verbal bullying dan semakin tinggi kepercayaan diri siswa.

Kepercayaan diri siswa yang tidak mengalami verbal bullying cenderung tinggi, mereka yang tidak mengalami verbal bullying cenderung ingin memilki banyak teman, jarang merasa khawatir serta bisa memahami pembelajaran dikelas, karena mereka tidak mendapatkan perlakuan bullying seperti mendapatkan perkataan kasar, diolok-olok, pengucilan serta pemfitnahan dari lingkungan sekitar, maka dari itu psikis mereka tidak terganggu sehingga mereka enjoy dalam menjalankan kehidupan tanpa merasa terbebani dengan kondisi disekitar, hal ini dibuktikan dengan hasil perolehan presentase yang rendah yaitu kurang dari $60 \%$, maka dapat disimpulkan 20 responden dari 30 responden tidak mengalami verbal bullying dan memiliki kepercayaan diri yang tinggi. Kepercayaan diri mempengaruhi kemandirian siswa dalam mengambil keputusan sendiri tanpa pengaruh dari orang lain, siswa yang mandiri mampu memotivasi diri untuk bertahan dari kesulitan yang dihadapi dan dapat menerima kegagalan dengan pikiran yang rasional. Seorang siswa yang memiliki kepercayaan diri dalam proses belajarnya dapat menerapkan sikap optimis serta bertanggungjawab dengan kewajiban yang dimilikinya sebagai siswa (Pratiwi \& Laksmiwati, 2016)

Menurut Hakim (2002; Harahap, 2019) banyak faktor yang mempengaruhi rasa kepercayaan diri pada individu, seperti lingkungan keluarga, pendidikan formal dan pendidikan non formal. Sekolah menjadi tempat strategis untuk pembentukan karakter dan penanaman nilai-nilai moral warga negara, karena anak-anak dari semua lapisan akan mendapatkan pendidikan formal ini (Ansulat Esmael, 2018). Dapat diketahui bahwa siswa lebih banyak menghabiskan waktu disekolah sehingga lingkungan sekolah dapat mempengaruhi karakteristik siswa. Oleh karena itu pendidikan sekolah harus bisa lebih memahami dan mengembangkan aspek-aspek yang ada pada diri siswa, misalnya kepercayaan diri yang merupakan aspek kehidupan yang penting. Tanpa adanya kepercayaan diri siswa akan mengalami kesusahan dala menghadapi permasalahan sebaliknya siswa yang memiliki keperayaan diri tinggi mereka akan lebih mudah untuk menjalani kehidupan.

\section{Perbedaan kepercayaan diri (self confidence) siswa yang mengalami verbal bullying dan kepercayaan diri (self confidence) siswa yang tidak mengalami verbal bullying.}

Berikut ini merupakan tabel hasil uji mann whitney dari data yang diperoleh dan diolah menggunakan spss 16 for windows untuk mengetahui ada tidaknya perbedaan kepercayaan diri siswa yang mengalami verbal bullying dan kepercayaan diri siswa yang tidak mengalami verbal bullying.

Tabel 3 Uji mann whitney

\begin{tabular}{cc}
\hline & Hasil \\
\hline Mann-Whitney U & .000 \\
\hline Wilcoxon W & 210.000 \\
\hline $\mathbf{Z}$ & -4.473 \\
\hline Asymp. Sig. (2-tailed) & .000 \\
\hline Exact Sig. [2*(1-tailed Sig.)] & $.000^{\mathrm{a}}$ \\
\hline
\end{tabular}

Berdasarkan hasil dari analisis uji hipotesis menggunakan spss 16 uji mann whitney atau U test diatas dapat diketahui bahwa nilai Asymp. Sig sebesar 0,000 sehingga dapat diketahui bahwa $0,000<0,05$ maka $h_{0}$ ditolak sedangkan $h_{1}$ diterima, sehingga ada perbedaan antara kepercayaan diri siswa yang mengalami verbal bullying dengan kepercayaan diri siswa yang tidak mengalami verbal bullying. Maslow menyatakan bahwa percaya diri merupakan modal dasar untuk pengembangan aktualis diri. Dengan percaya diri orang akan mampu mengenal dan memahami diri sendiri. Sementara itu, kurangnya, percaya diri akan menghambat 
3557 Studi Komparasi Kepercayaan Diri (Self Confidance) Siswa yang Mengalami Verbal Bullying dan Yang Tidak Mengalami Verbal Bullying di Sekolah Dasar-Indriana Ulul Azmi, Nafi'ah, Muhammad Thamrin, Akhwan

DOI: https://doi.org/10.31004/basicedu.v5i5.1389

pengembangan potensi diri. Jadi orang yang kurang percaya diri akan menjadi seseorang yang pesimis dalam menghadapi tantangan, takut dan ragu-ragu untuk menyampaikan gagasan, serta bimbang dalam menentukan pilihan dan sering membanding-bandingkan dirinya dengan orang lain (M. Nur Ghufron dan Rini Risnawita S, 2019).

Hasil penelitian ini sejalan dengan hasil penelitian yang dilakukan oleh Talisa Winahayu yang berjudul "Dampak verbal bullying terhadap kecerdasan interpersonal siswa kelas II SD muhammadiyah gendol Yogyakarta". Penelitian tersebut mengungkapkan bahwa terdapat perbedaan antara siswa yang mengalami verbal bullying dan yang tidak mengalami verbal bullying, siswa yang diejek temannya dengan dikatai "goblok" dan "dancuk" terkadang merasa sedih dan tidak ingin temannya melakukan hal itu lagi, mereka merasa tidak berguna dan menghindari untuk berteman dengan teman yang lainnya, mereka juga minder dan tidak percaya diri untuk melakukan sesuatu, sehingga mereka mengalami kesulitan untuk mengembangkan potensi mereka.

Kepercayaan diri bukan merupakan bakat melainkan kualitas mental yang dimiliki yang artinya bahwa kepercayaan diri merupakan pencapaian yang dihasilkan dari proses pendidikan atau pembelajaran. Dengan demikian keperayaan diri tebentuk melalui proses interaksi dilingkungannya. Lauster (1978; Sam \& Manado, 2016) mengatakan bahwa rasa percaya diri bukan merupakan sifat yang diturunkan atau bawaan melainkan diperoleh dari pengalaman hidup, serta dapat diajarkan dan ditanamkan melalui pendidikan, sehingga upayaupaya tertentu dapat dilakukan guna membentuk dan meningkatkan rasa percaya diri. Meskipun kepercayaan diri diidentikan dengan kemandirian, orang yang kepercayaan dirinya tinggi umumnya lebih mudah terlibat secara pribadi dengan orang lain dan lebih berhasil dalam hubungan interpersonal.

\section{KESIMPULAN}

Berdasarkan hasil analisis data dan pembahasan yang telah dilakukan maka dapat ditarik kesimpulan bahwa kepercayaan diri siswa yang mengalami verbal bullying cenderung rendah, mereka jarang bisa memahami sesuatu, mereka juga selalu mengkhawatirkan tentang masa depan. Hal ini dibuktikan dengan perolehan hasil perhitungan sebesar 64,7\% dengan frekuensi 6 dan 70,4\% dengan frekuensi 4. Perolehan skor tergolong tinggi jika di interpretasikan dalam skala 60\%-80\%. Kepercayaan diri rendah dapat dilihat dari presentase indikator dari kepercayaan diri, siswa yang mengalami verbal bullying mereka akan mengalami kesusahan untuk bersosialisasi, tidak suka jika memiliki banyak teman dan susah untuk memahami pembelajaran. Sedangkan untuk kepercayaan diri siswa yang tidak mengalami verbal bullying cenderung tinggi, mereka tidak mendapatkan tindakan verbal bullying, dibuktikan dengan perolehan skor presentase $<60 \%$ yang tergolong dalam kategori yang rendah. Mereka tidak mendapatkan perkataan kasar, diolok-olok, pengucilan serta pemfitnahan dari lingkungan sekitar, maka dari itu psikis mereka tidak terganggu sehingga mereka enjoy dalam menjalankan kehidupan tanpa merasa terbebani dengan kondisi disekitar. terdapat Perbedaan yang cukup signifikan antara kepercayaan diri siswa yang mengalami verbal bullying dengan kepercayaan diri siswa yang tidak mengalami verbal bullying terlihat dari hasil berdasarkan hasil dari analisis uji hipotesis menggunakan spss 16 uji mann whitney atau U test diatas dapat diketahui bahwa nilai Asymp. Sig sebesar 0,000 sehingga dapat diketahui bahwa $0,000<0,05$ maka $h_{0}$ ditolak sedangkan $h_{1}$ diterima, sehingga ada perbedaan antara kepercayaan diri siswa yang mengalami verbal bullying dengan kepercayaan diri siswa yang tidak mengalami verbal bullying. 
3558 Studi Komparasi Kepercayaan Diri (Self Confidance) Siswa yang Mengalami Verbal Bullying dan Yang Tidak Mengalami Verbal Bullying di Sekolah Dasar-Indriana Ulul Azmi, Nafi'ah, Muhammad Thamrin, Akhwan

DOI: https://doi.org/10.31004/basicedu.v5i5.1389

\section{DAFTAR PUSTAKA}

Amri, S. (2018). Pengaruh Kepercayaan Diri (Self Confidence) Berbasis Ekstrakurikuler Pramuka Terhadap Prestasi Belajar Matematika Siswa Sma Negeri 6 Kota Bengkulu. Jurnal Pendidikan Matematika Raflesia, 03(02), 156-168. Https://Ejournal.Unib.Ac.Id/Index.Php/Jpmr/Article/View/7520

Ansulat Esmael, D. (2018). Edustream: Jurnal Pendidikan Dasar Implementasi Pendidikan Karakter Religius Di Sekolah Dasar Khadijah Surabaya. Ii(1).

Astuti, I., \& Yusuf, A. (2015). Perilaku Bullying Verbal Pada Peserta Didik Kelas Ix. 1-9.

Dewi, L., \& Nathania, S. (2018). Pengukuran Aspek Kepuasan Konsumen Le Fluffy Dessert. Jurnal Bisnis Terapan, 2(01), 61-72. Https://Doi.Org/10.24123/Jbt.V2i01.1087

Fatchurahman, M., \& Praktikto, H. (2012). Demokratis Dan Kenakalan Remaja. Psikologi Indonesia, 1(2), $77-87$.

Fitri, E., Zola, N., \& Ifdil, I. (2018). Profil Kepercayaan Diri Remaja Serta Faktor-Faktor Yang Mempengaruhi. Jppi (Jurnal Penelitian Pendidikan Indonesia), 4(1), 1. Https://Doi.Org/10.29210/02017182

Harahap, J. Y. (2019). Kepercayaan Diri Dalam Belajar Pada Mahasiswa Yang Sudah Dan Yang Belum Bekerja. Journal Of Chemical Information And Modeling, 4(November), 103-110.

Harmila, D., Rais, R., \& Fadjryani, F. (2017). Analisis Keaktifan Mahasiswa Jurusan Matematika Fakultas Mipa Universitas Tadulako Dengan Metode Mann Whitney. Jurnal Ilmiah Matematika Dan Terapan, 12(2), 104-114. Https://Doi.Org/10.22487/2540766x.2015.V12.I2.7903

Junaida, H. K. C. (2016). Meningkatkan Percaya Diri Dan Hasil Belajar Siswa Melalui Pengembangan Modul Mata Pelajaran Mmeberikan Pelayanan Kepada Pelanggan Guided Inquiry. Jurnal Ilmu Pendidikan, 2(1), 75-93.

Kelas, S., Studi, V. I. I., Marta, D., \& Supriyo, D. (2013). Kepercayaan Diri Ditinjau Dari Pola Asuh Orang Tua Pada Siswa Kelas Vii (Studi Kasus). Indonesian Journal Of Guidance And Counseling, 2(4), 9-16.

M. Nur Ghufron Dan Rini Risnawita S. (2019). Kepercayaan Diri. Jurnal Penelitian Pendidikan, 5(1), 16891699.

Prasetiawan, H., \& Saputra, W. N. E. (2018). Profil Tingkat Percaya Diri Siswa Smk Muhammadiyah Kota Yogyakarta. Counsellia: Jurnal Bimbingan Dan Konseling, $8(1), \quad 19$. Https://Doi.Org/10.25273/Counsellia.V8i1.2248

Pratiwi, I. D., \& Laksmiwati, H. (2016). Kepercayaan Diri Dan Kemandirian Belajar Pada Siswa Sma Negeri “X.” Jurnal Psikologi Teori Dan Terapan, 7(1), 43. Https://Doi.Org/10.26740/Jptt.V7n1.P43-49

Ramadhani, T. N., \& Putrianti, F. G. (2014). 13. 256852-Hubungan-Antara-Kepercayaan-Diri-DenganD719764a. Jurnal Psikologi Sarjanawiyata Tamansiswa Yogyakarta, 4, 22-32.

Remaja, P., Smp, D. I., \& Kundre, R. (2018). Hubungan Bullying Dengan Kepercayaan Diri Pada Remaja Di Smp Negeri 10 Manado. Jurnal Keperawatan, 6(1), 1-6.

Rosyida. (2013). Perbedaan Tingkat Kepercayaan Diri (Self Confident) Ditinjau Dari Posisi Urutan Kelahiran (Birthorder) Mahasiswa Fakultas Psikologi Uin Maliki Malang. 1, 12-39.

Sam, U., \& Manado, R. (2016). Hubungan Kepercayaan Diri Dengan Penyesuaian Diri Pada Mahasiswa Baru Di Program Studi Ilmu Keperawatan Fakultas Kedokteran Universitas Sam Ratulangi Manado. Jurnal Keperawatan, 4(2).

Saputra, W. N. E., \& Prasetiawan, H. (2018). Meningkatkan Percaya Diri Siswa Melalui Teknik Cognitive Defusion. Jurnal Kajian Bimbingan Dan Konseling, 3(1), 14-21. Https://Doi.Org/10.17977/Um001v3i12018p014 
3559 Studi Komparasi Kepercayaan Diri (Self Confidance) Siswa yang Mengalami Verbal Bullying dan Yang Tidak Mengalami Verbal Bullying di Sekolah Dasar-Indriana Ulul Azmi, Nafi'ah, Muhammad Thamrin, Akhwan

DOI: https://doi.org/10.31004/basicedu.v5i5.1389

Surakhmad, W. (2016). Pengertian Komparasi. 6-9. Http://E-Journal.Uajy.Ac.Id/8883/3/2mts02204.Pdf

Yustia Putri, W. (2017). Pengaruh Regulator, Kepemilikan Institusional, Ukuran Perusahaan, Dan Profitabilitas Terhadap Carbon Emission Disclosure (Studi Pada Perusahaan Manufaktur Yang Terdaftar Di Bei Tahun 2014-2016). Fakultas Ekonomi Dan Bisnis, Unpas Bandung, 48-83. Http://Repository.Unpas.Ac.Id/30262/7/Bab 3 Sa.Pdf 